\title{
APLIKASI PENERIMAAN DAN PENYELEKSIAN MAHASISWA BARU UNIVERSITAS ANDI DJEMMA
}

\author{
Ahmad Ali Hakam Dani ${ }^{1)}$, Herlina ${ }^{2)}$ \\ 1) Dosen Program Studi Teknik Informatika Universitas Andi Djemma \\ ${ }^{2)}$ Program Studi Teknik Informatika Universitas Andi Djemma \\ 1) ahmad.ali@unanda.ac.id \\ ${ }^{2)}$ herlina_linaa@yahoo.com
}

\begin{abstract}
Abstrak
Penelitian ini bertujuan untuk membuat aplikasi penerimaan dan penyeleksian mahasiswa baru di Universitas Andi Djemma. Metode penelitian ini menggunakan metode kualitatif dengan jenis deskriptif. Sedangkan metode pengumpulan data menggunakan metode wawancara, dokumentasi dan studi pustaka. Sistem informasi perpustakaan ini dalam perancangannya juga menggunakan metode pengembangan UML (Unified Modeling Language) yang terdiri dari Use Case Diagram, Activity Diagram, Sequence Diagram dan Class Diagram. Adapun software yang digunakan dalam perancangan dan pengimplementasian sistem menggunakan PHP sebagai Bahasa pemrograman yang digunakan untuk membangun aplikasi, MySQL sebagai database, Adobe Dreamweaver sebagai editor desain web. Aplikasi penerimaan dan penyeleksian ini berbasis web yang terdiri dari dua aktor yaitu Admin dan Calon Mahasiswa Baru. Halaman aplikasi yang dapat dibuka oleh Calon Mahasiswa Baru terdiri dari: halaman login calon mahasiswa baru, halaman beranda, halaman aturan dan prosedur, halaman pendaftaran, halaman data diri, halaman kerjakan soal, sedangkan untuk Admin terdiri dari: Halaman login admin, halaman beranda, halaman data pendaftaran, halaman data nilai, halaman kelola soal, halaman cetak data pendaftaran.
\end{abstract}

Kata kunci: Aplikasi, Penerimaan, Penyeleksian, Unified Modelling Language, PHP, MySQL, Web.

\section{PENDAHULUAN}

Pemanfaatan teknologi yang meluas membuat organisasi, perusahaan bahkan institusi berlomba menggunakan teknologi untuk mencapai tujuan yang diharapkan secara optimal. Tujuan organisasi terutama institusi pendidikan khususnya dapat mendapatkan kuantitas peserta didik baik siswa maupun mahasiswa sehingga nama institusi tersebut dengan cepat dan mudah dikenal oleh masyarakat baik yang akan melanjutkan jenjang pendidikan maupun hanya sekedar untuk mendapatkan informasi.

Penggunaan teknologi informasi sangat berdampak pada dunia pendidikan, khususnya pada Penerimaan Mahasiswa Baru (PMB) di sebuah perguruan tinggi atau universitas. Dalam proses PMB tersebut komputer sangat diperlukan guna mengolah data-data yang berhubungan dengan penerimaan mahasiswa baru, sebab komputer merupakan suatu perangkat elektronik yang dapat menerima masukan (input) dan selanjutnya melakukan pengolahan (process) untuk menghasilkan keluaran (output) berupa informasi. Data-data yang dihasilkan dalam penerimaan mahasiswa baru dapat diolah sedemikian rupa sehingga dapat diorganisir dalam suatu sistem yang terkomputerisasi atau bisa disebut juga dengan Aplikasi Penerimaan Mahasiswa Baru. Universitas Andi Djemma adalah salah satu Perguruan Tinggi Swasta (PTS) yang berada di Kota Palopo yang didirikan pada tanggal 23 januari 1995 Oleh Yayasan To Ciung Luwu dan mulai beroperasi pada tanggal 14 september 1998. Sejak didirikan hingga saat ini Universitas Andi Djemma menggunakan sistem manual dalam penerimaan dan penyeleksian mahasiswa baru. Peningkatan jumlah calon mahasiswa setiap tahunnya membuat sistem manual ini tidak efektif. Jumlah panitia penerimaan mahasiswa baru yang terbatas membuat pengarsipan data calon mahasiswa baru membutuhkan waktu yang lebih dari jadwal pengumpulan formulir yang seharusnya 
sehingga membuat calon mahasiswa tidak dapat mengetahui status pendaftarannya dengan cepat, termasuk jika terjadi ketidaklengkapan persyaratan pendaftaran. Hal ini menyebabkan jadwal dan hasil tes penyeleksian sering terlambat dari jadwal seharusnya. Sistem yang ada sekarang kurang efektif karena calon mahasiswa baru harus datang langsung ke kampus untuk mengambil formulir dan mengisinya kemudian mengumpulkannya kembali ke panitia penerimaan mahasiswa baru. Selanjutnya calon mahasiswa baru mengikuti semua prosedur secara manual sampai calon mahasiswa tersebut diterima di Universitas Andi Djemma. Sedangkan dalam proses penyelenggaraan kegiatan penerimaan dan penyeleksian mahasiswa baru, dituntut adanya suatu kecepatan dan keakuratan dalam pengolahan pendataan calon mahasiswa tersebut antara lain berupa pembuatan biodata mahasiswa, pembuatan kartu tes dan pengumuman hasil tes mahasiswa diterima atau tidak. Oleh karena itu dirasa perlu adanya aplikasi penerimaan dan penyeleksian mahasiswa baru di Universitas Andi Djemma dengan harapan agar proses penerimaan mahasiswa baru menjadi lebih efektif dan efisien serta mempermudah panitia penerima mahasiswa baru dalam mengelola data calon mahasiswa baru.

\section{METODOLOGI PENELITIAN}

Alur penelitian ini dapat dilihat pada diagram alir berikut ini:

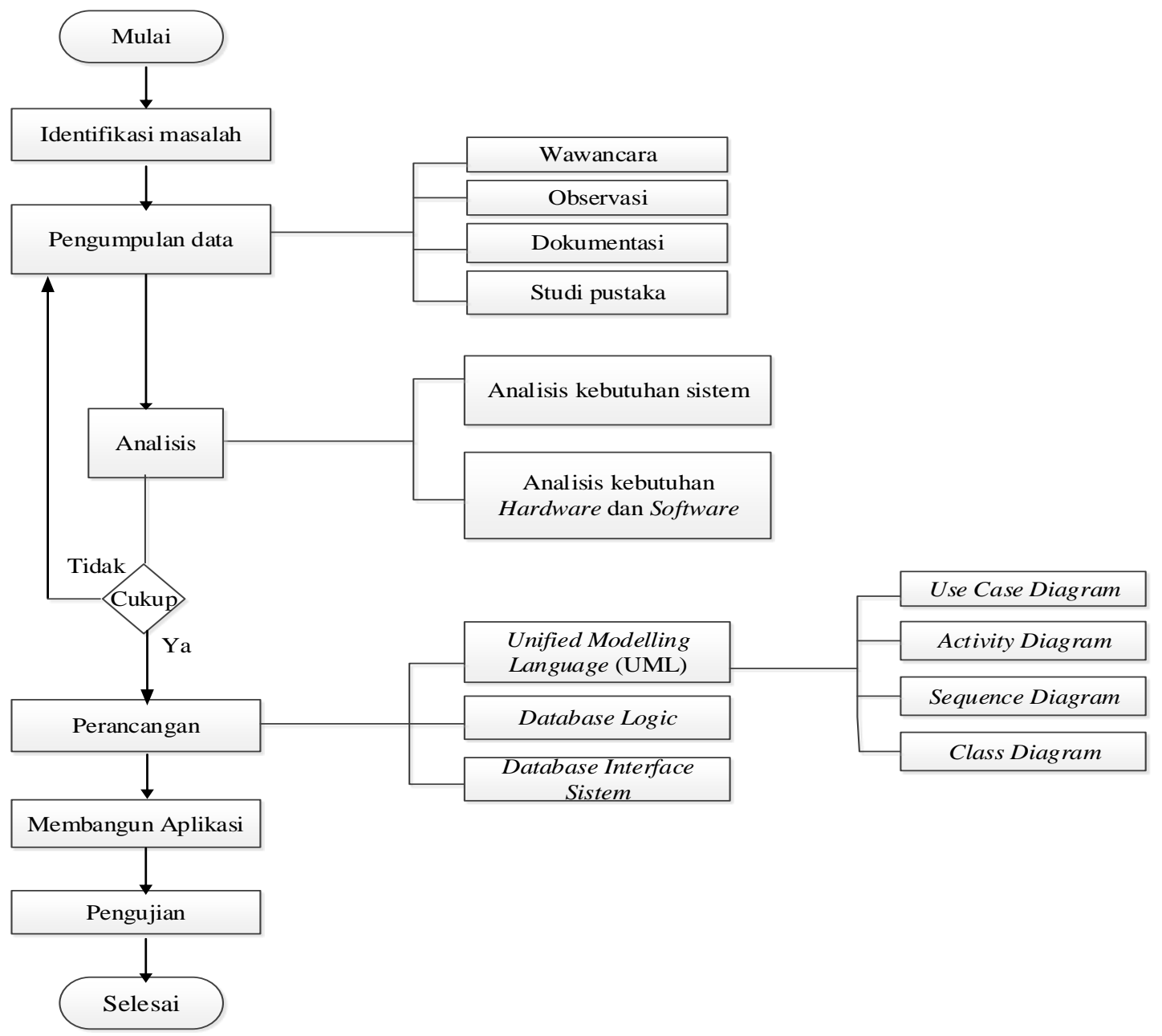

Gambar 1. Diagram Alir Penelitian 


\section{HASIL DAN PEMBAHASAN}

Analisis Sistem yang Diusulkan

Pada gambar di bawah alur sistem yang diusulkan yaitu calon mahasiswa baru terlebih dahulu melakukan transfer ke rekening Universitas Andi Djemma, setelah itu calon mahasiswa baru mengakses website PMB dan membuka menu pendaftaran. Calon mahasiswa menginput data sesuai permintaan data inputan pada halaman pendaftaran setelah itu calon mahasiswa mengklik tombol kirim atau save. Jika masih ada data yang kosong maka sistem akan memunculkan peringatan untuk menginput kembali data yang kosong, akan tetapi jika tidak ada maka sistem akan menyimpan data tersebut. Selanjutnya calon mahasiswa baru dapat mencetak kartu pendaftaran. Calon mahasiswa login dengan memasukan user dan password sesuai dengan input pada saat melakukan pendaftaran. Apabila login sukses maka calon mahasiswa dapat melihat informasi di halaman utama dan sudah bisa mengerjakan Soal TKDA dan Soal Bahasa Inggris. Tahapan akhir, calon mahasiswa baru dapat melihat pengumuman.

Adapun perancangan sistem yang diusulkan adalah sebagai berikut:

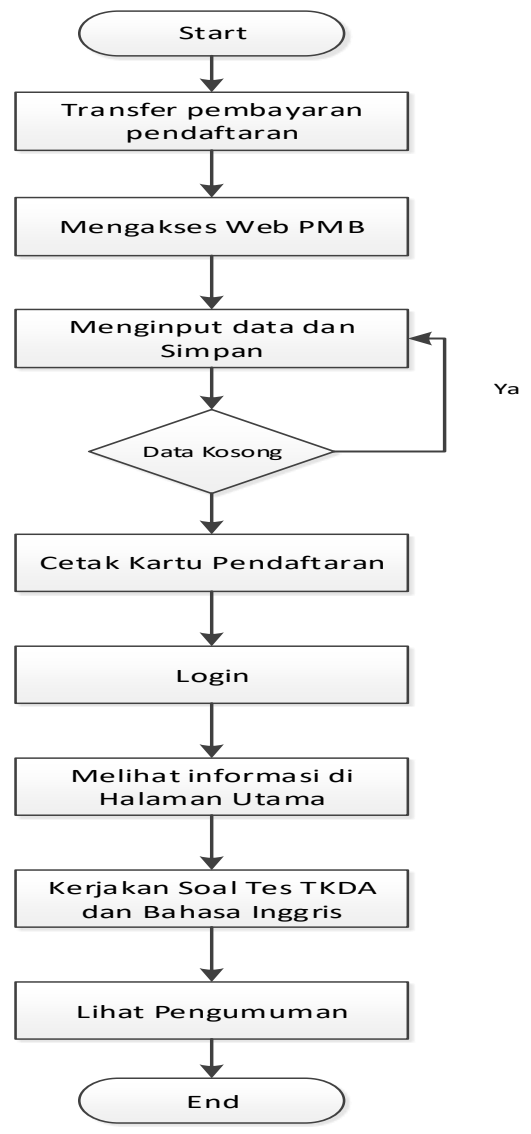

Gambar 2: Bagan Alir Sistem Usulan

\section{Use Case Diagram}

Rancangan Use Case Diagram dapat dilihat sebagai berikut: 


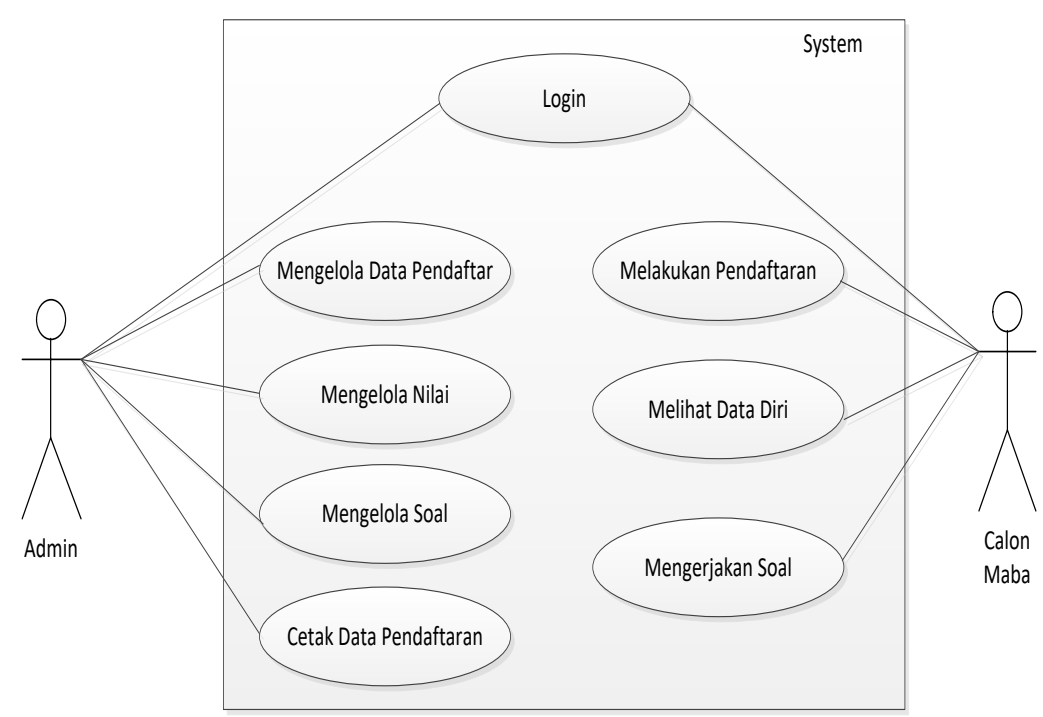

Gambar 2: Use Case Diagram

Dari diagram use case di atas dapat dijelaskan bahwa admin melakukan login terlebih dahulu untuk mengakses sistem, admin dapat mengelola data pendaftar dalam hal ini data calon mahasiswa baru, admin dapat mengelola nilai tes dari calon mahasiswa, admin dapat mengelola soal tes, dan juga admin dapat mencetak data pendaftaran. Adapun calon mahasiswa baru dapat melakukan pendaftaran jika telah selesai melakukan pendaftaran maka calon mahasiswa baru dapat login jika sudah diaktivasi oleh admin, calon mahasiswa baru juga dapat mengerjakan soal tes ujian masuk.

\section{Activity Diagram}

Activity Diagram Login

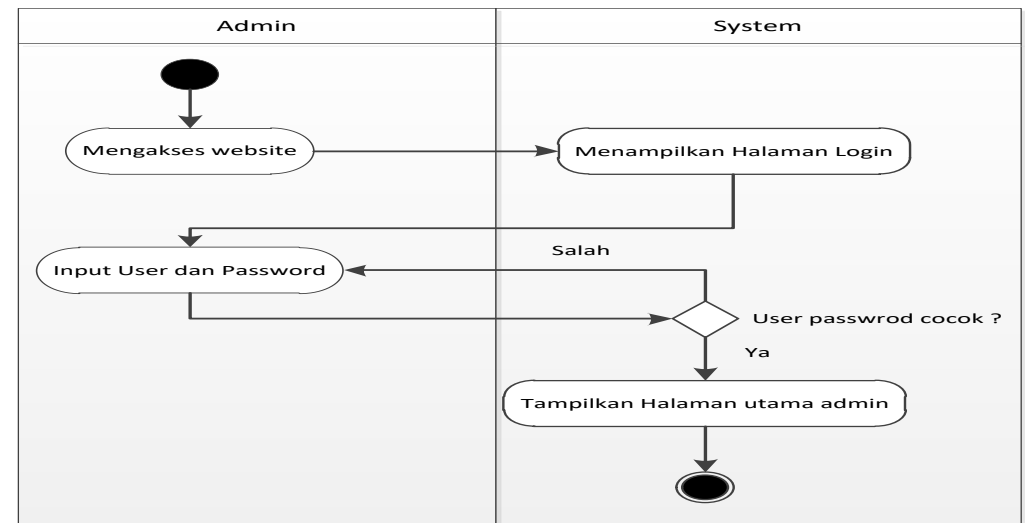

Gambar 3: Activity Diagram Login Admin 
Activity Diagram Konfirmasi Data Pendaftar Baru

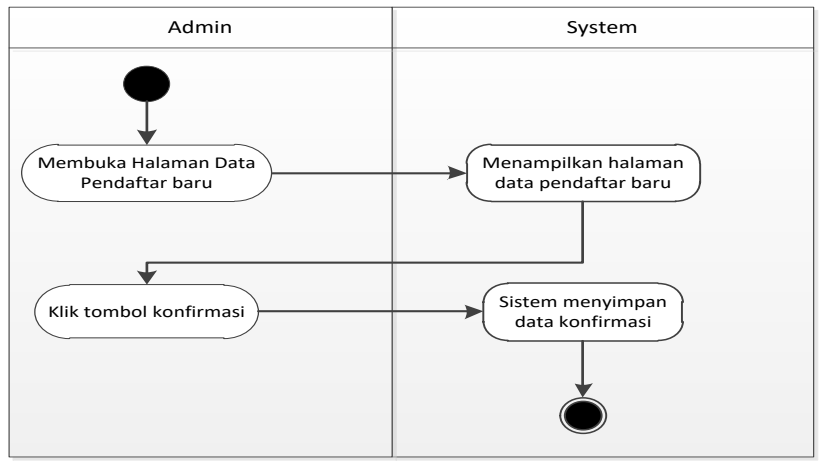

Gambar 4: Activity Diagram Konfirmasi Data Pendaftar Baru Activity Diagram Nilai Tes

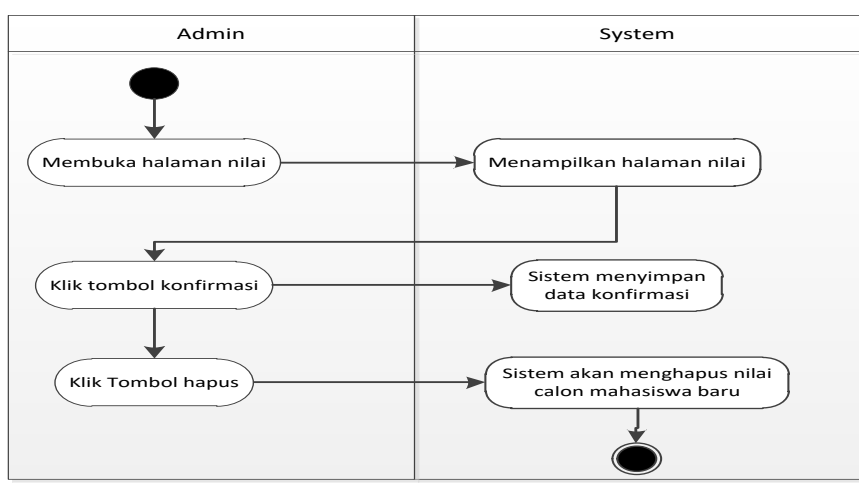

Gambar 5: Activity Diagram Nilai Tes

Activity Diagram Input Soal Tes

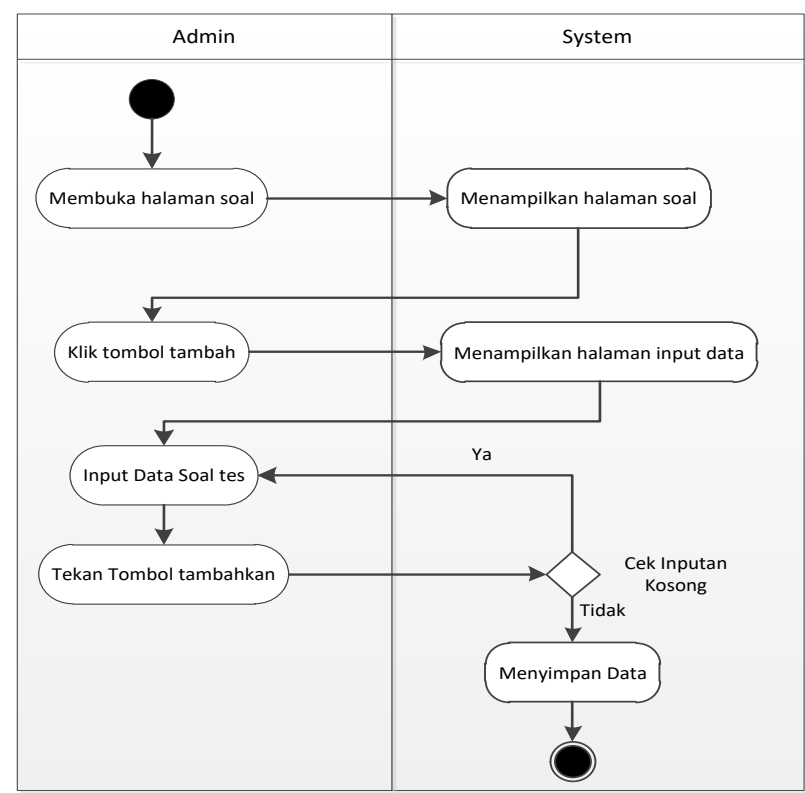

Gambar 6: Activity Diagram Input Soal Tes 
Activity Diagram Cetak Data Pendaftaran

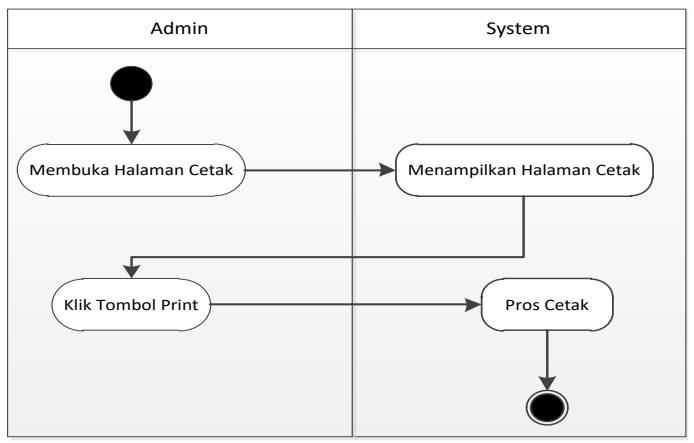

Gambar 7: Activity Diagram Cetak Data Pendaftaran Activity Diagram Input Data Pendaftaran

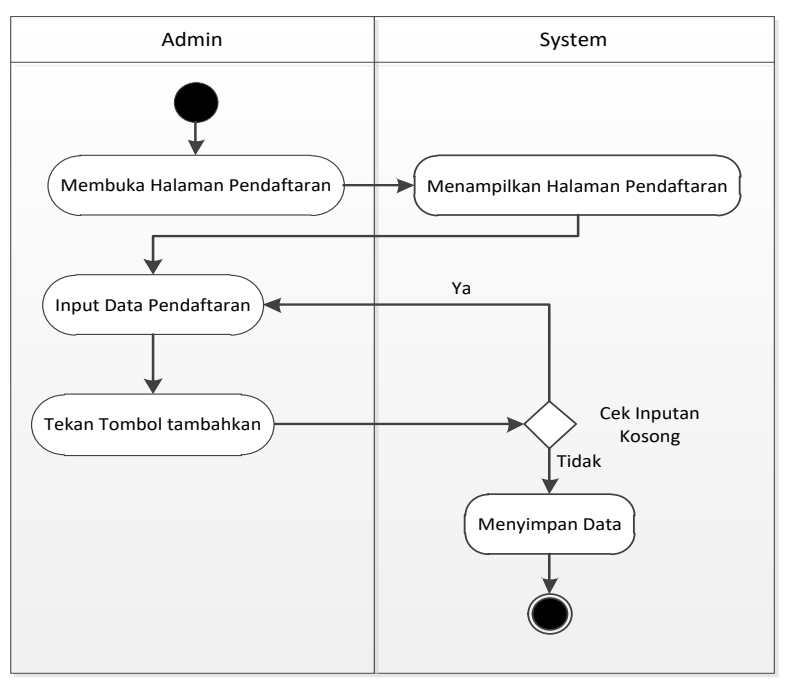

Gambar 8: Activity Diagram Input Pendaftaran Activity Diagram Mengerjakan Soal

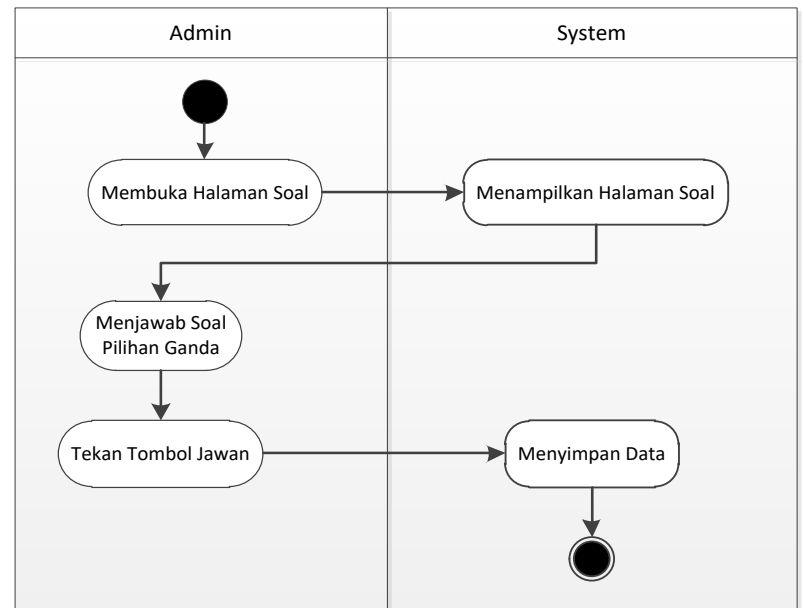

Gambar 9: Activity Diagram Mengerjakan Soal 


\section{Sequence Diagram}

Sequence Diagram Login

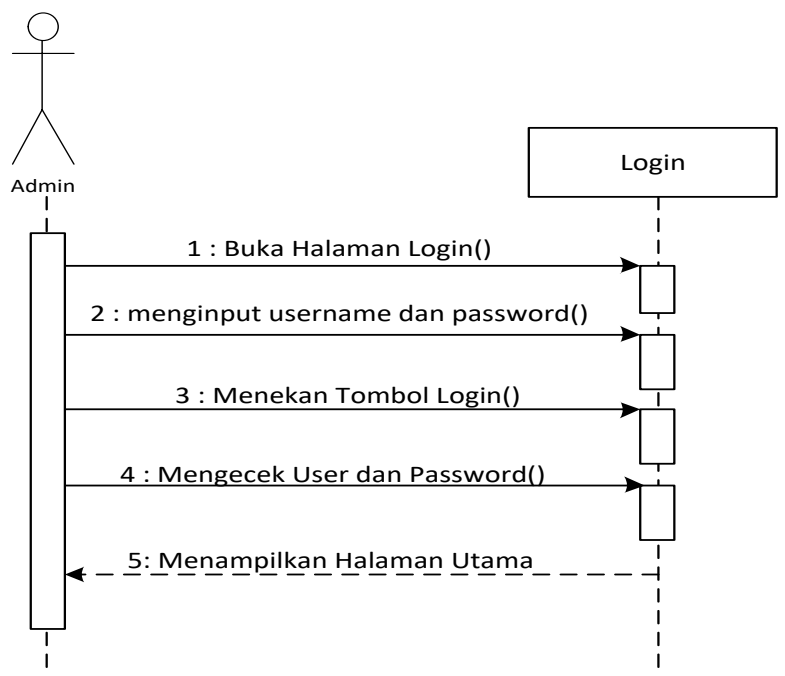

Gambar 10. Sequence Diagram Login

Dari diagram sequence di atas dapat dilihat bahwa aktor admin membuka atau mengakses halaman login, setelah itu admin memasukan user dan password dan menekan tombol login setelah itu system akan melakukan validasi atau pengecekan dan selanjutnya sistem akan memunculkan menu utama.

Sequence Diagram Data Pendaftaran

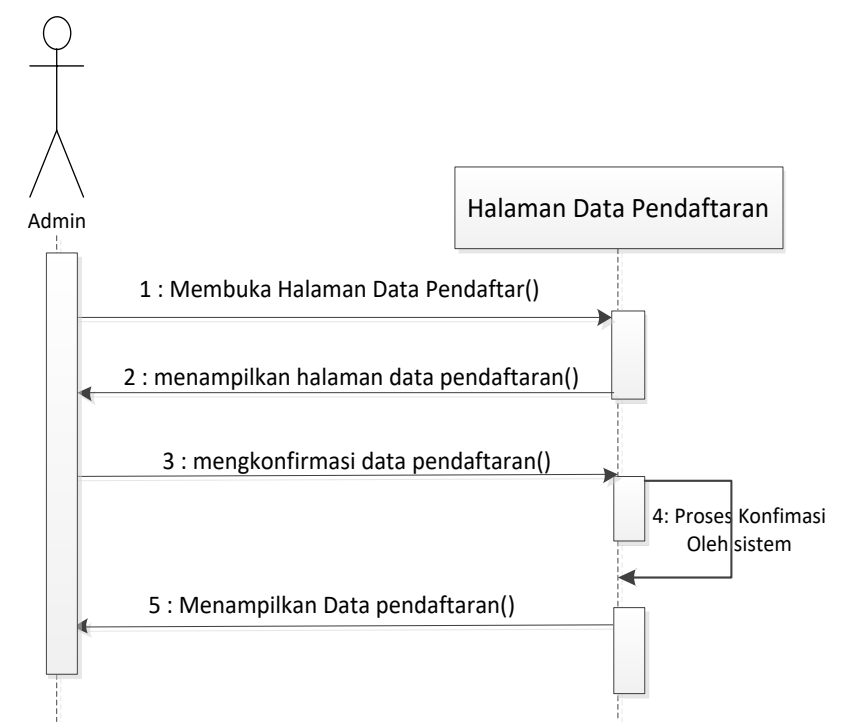

Gambar 11: Sequence Diagram Data Pendaftaran

Dari diagram sequence diatas dapat dilihat bahwa aktor admin membuka halaman data pendaftaran, setelah itu sistem menampilkan data pendaftaran. Admin mengkonfirmasi data pendaftaran dan sistem akan memproses konfirmasi tersebeut dan selanjutnya siystem akan menampilkan data pendaftaran. 


\section{Sequence Diagram Nilai Tes}

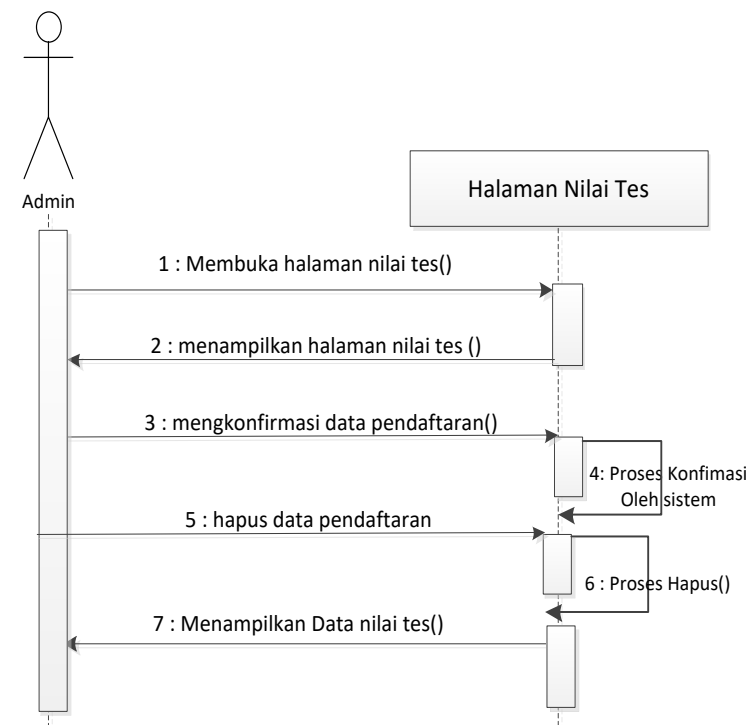

Gambar 12: Sequence Diagram Nilai Tes

Dari diagram sequence di atas dapat dilihat bahwa aktor admin membuka halaman nilai tes, setelah itu sistem menampilkan nilai tes. Admin mengkonfirmasi data nilai tes dan sistem akan memproses konfirmasi tersebut. Admin juga dapat melakukan hapus data dan sistem akan memproses untuk menghapus nilai tes tersebut, sistem juga akan menampilkan nilai tes.

Sequence Diagram Input Soal

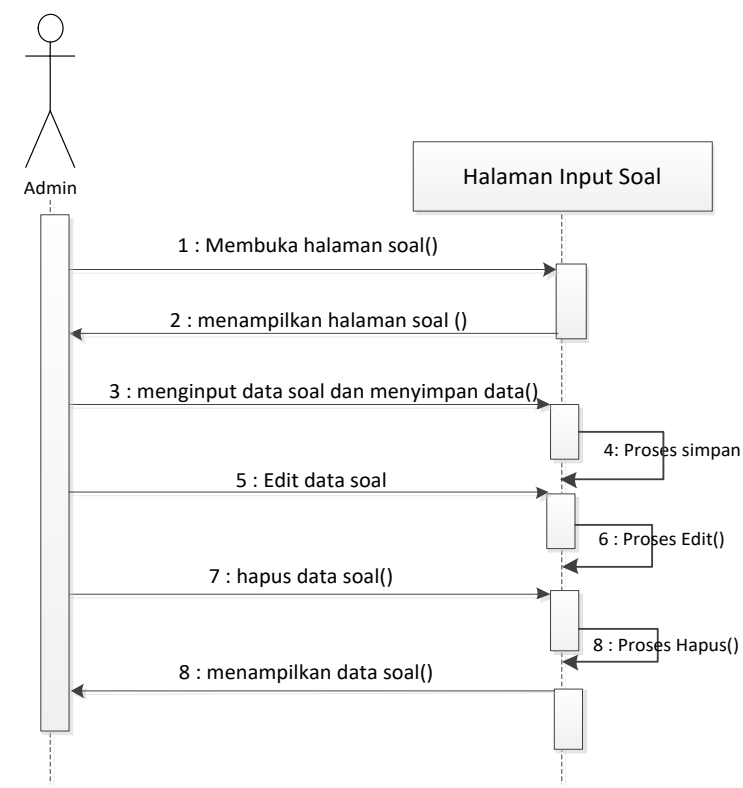

Gambar 13: Sequence Diagram Input Soal

Dari diagram sequence diatas dapat dilihat bawha aktor admin membuka halaman input soal, setelah itu sistem menampilkan input soal. Admin dapat menginput mengedit 
dan menghapus data soal. Sedangkan sistem akan melakukan proses simpan, edit, dan proses hapus, admin juga dapat melihat data soal.

Sequence Diagram Cetak Data Pendaftaran

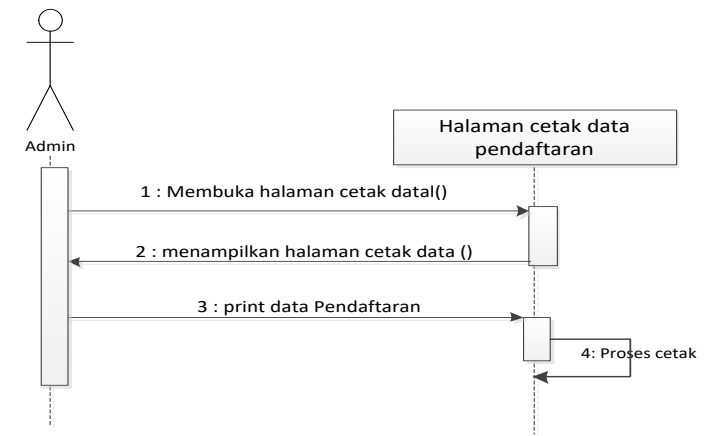

Gambar 14: Sequence Diagram Cetak Data Pendaftaran

Dari diagram sequence diatas dapat dilihat bawha aktor admin membuka halaman cetak data pendaftaran. Admin dapat mengklik tombol print dan sistem akan melakukan proses cetak.

Sequence Diagram Pendaftaran

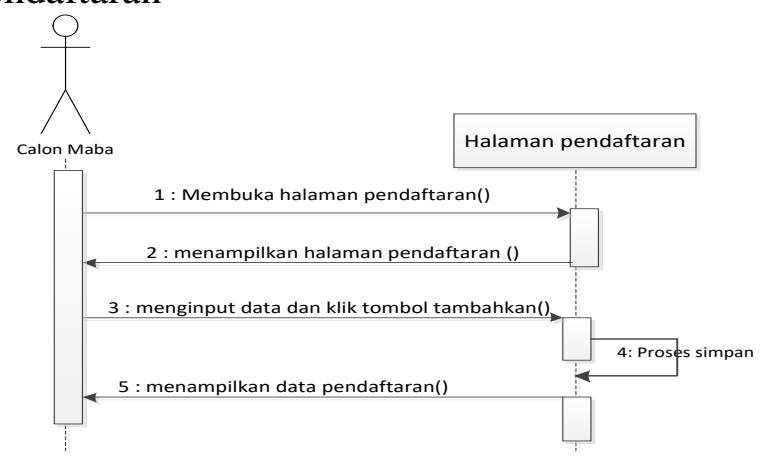

Gambar 15: Sequence Diagram Pendaftaran

Terlihat bawha aktor calon mahasiswa baru membuka halaman pendaftaran. Calon mahasiswa menginput data dan setelah itu menekan tombol tambahkan, selanjutnya sistem melakukan proses simpan data. Sistem juga akan menampilkan data pendaftaran. Sequence Diagram Kerja Soal

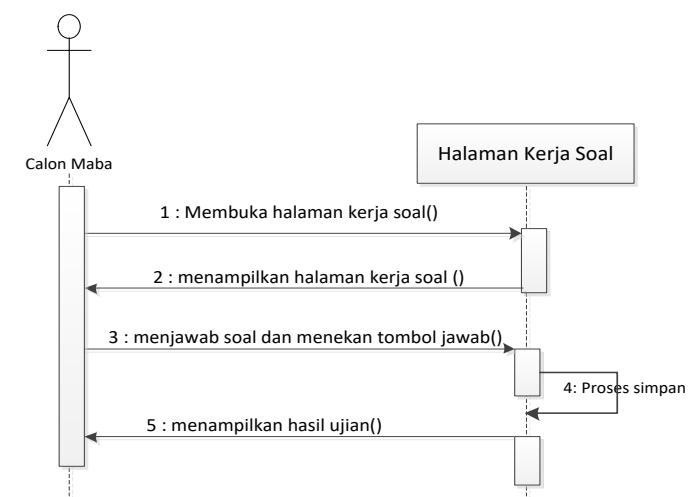

Gambar 16: Sequence Diagram Kerja Soal 
Terlihat bawha aktor calon mahasiswa baru membuka halaman kerja soal. Calon mahasiswa memilih jawaban dan menekan tombol jawab, selanjutnya sistem melakukan proses simpan data. Sistem akan menampilkan data hasil ujian tes.

\section{Class Diagram}

\begin{tabular}{|l|}
\hline \multicolumn{1}{|c|}{ Class Pendaftaran } \\
\hline - id_pendaftaran: int \\
- kode_pendaftaran: varchar \\
- kelompokuji: varchar \\
- prodi1: varchar \\
- prodiz: varchar \\
- status_calon: varchar \\
- nama_calon: varchar \\
- tempat_lahir: varchar \\
- tanggal_lahir: date \\
-jk: varchar \\
- agama: varchar \\
- sekolah_asal:varchar \\
-jurusan: varchar \\
- tahunijasah: varchar \\
- nilai_uan: varchar \\
- alamat: varchar \\
- nama_ortu: varchar \\
- pekerjaan_ortu: varchar \\
- alamat__ortu: varchar \\
- hp_ortu: varchar \\
- kota: varchar \\
- provinsi: varchar \\
- hp_calon: varchar \\
- tahun_daftar: varchar \\
- status: varchar \\
- userlogin: varchar \\
- passwlogin: varchar \\
- foto: text \\
\hline + buka Hal. Pendaftaran() \\
+tampilkan pendaftaran() \\
+ Input Datal) \\
+Simpan Datat) \\
\hline
\end{tabular}

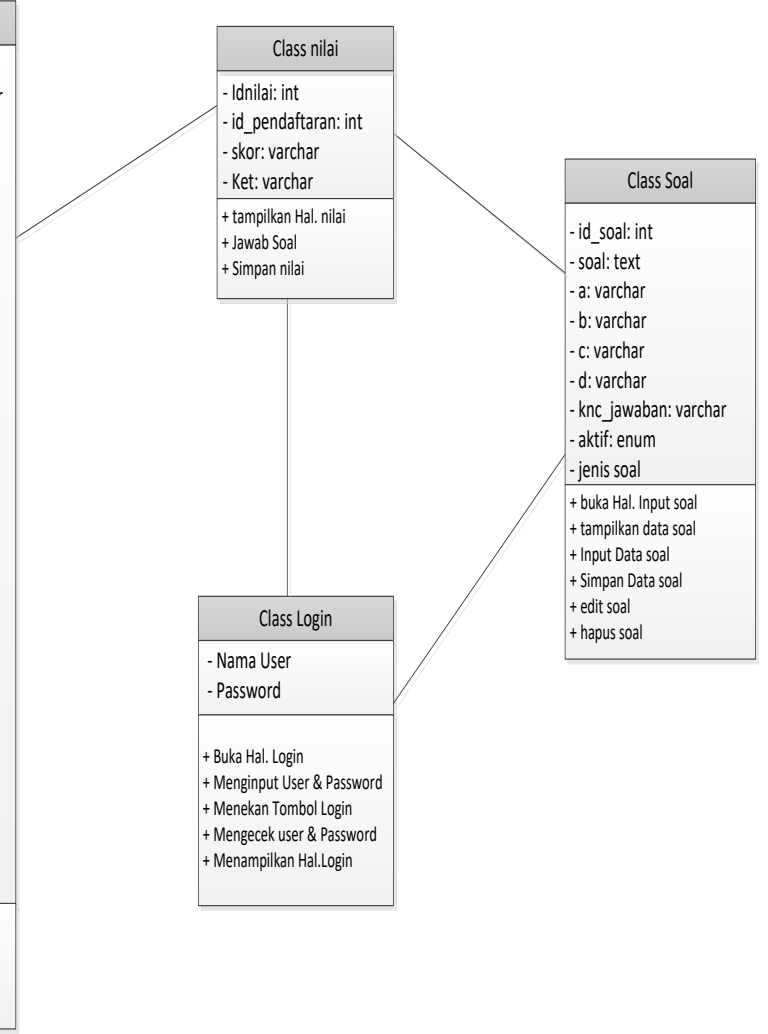

\section{1) User Interface}

\section{Gambar 17: Class Diagram}

Beberapa tampilan user interface dari aplikasi yang dibangun yaitu: Halaman Login

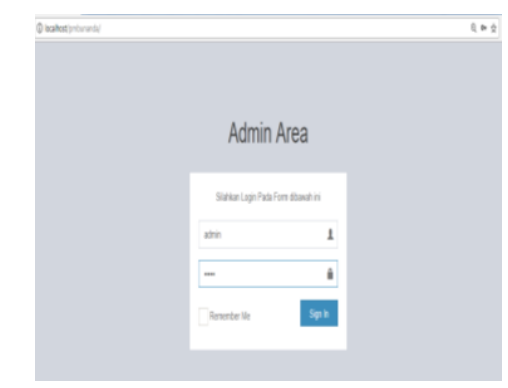

Gambar 18: Halaman Login

Halaman Input Data Pendaftaran

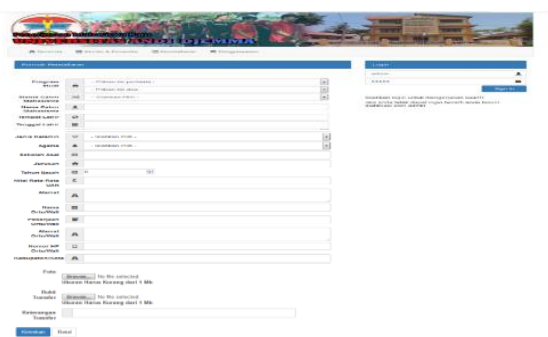

Gambar 19: Halaman Input Data Pendaftaran 
Halaman Mengerjakan Soal Tes

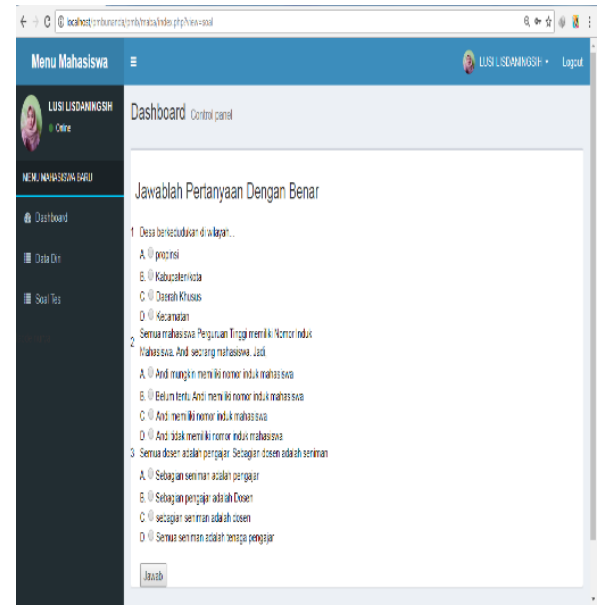

Gambar 20: Halaman Mengerjakan Soal Tes Halaman Dashboard Admin

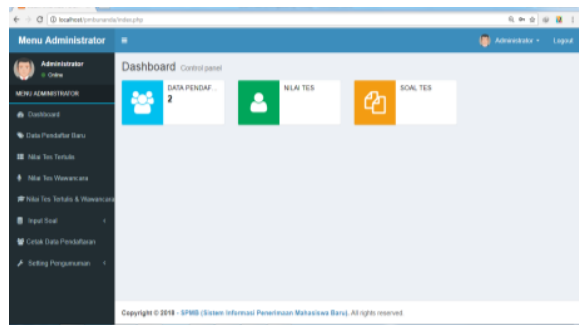

\section{Gambar 21: Halaman Dashboard Admin}

\section{Pengujian}

Pengujian merupakan bagian dari pengukuran yang artinya memiliki jawaban yang benar atau salah. Pada tahapan ini akan dilakukan pengujian sistem untuk memeriksa apakah aplikasi yang dihasilkan sudah dapat dijalankan sesuai dengan standar tertentu. Pengujian sistem merupakan hal terpenting yang bertujuan untuk menemukan kesalahan-kesalahan pada aplikasi yang telah dibuat. Adapun teknik pengujian yang telah dilakukan yaitu menggunakan pengujian black box. Pengujian ini berfokus pada persayaratan fungsional perangkat lunak. Pengujian dilakukan guna memeriksa secara singkat keakuratan sistem. Berdasarkan hasil pengujian black box, diperoleh bahwa semua halaman menu pada aplikasi berjalan sesuai yang diharapkan atau berhasil mengeksekusi coding dengan benar.

\section{KESIMPULAN}

Berdasarkan hasil penelitan dan pembahasan yang dilakukan terhadap aplikasi penerimaan dan penyeleksian mahasiswa baru ini, maka dapat disimpulkan bahwa Aplikasi Penerimaan dan Penyeleksian Mahasiswa Baru ini dapat memudahkan calon mahasiswa baru dalam melakukan pendaftaran meski tidak datang di Universitas Andi Djemma untuk mendaftar dan juga dapat mengurangi pekerjaan administrator (Panitia PMB) dalam mengelola data calon mahasiswa baru. Aplikasi ini berjalan dengan baik dan dapat diakses melalui http://www.pmbunanda.16mb.com pada address bar di web browser. 


\section{DAFTAR PUSTAKA}

Hendrianto, Dani Eko. (2014). Pembuatan Sistem Informasi Perpustakaan Berbasis Website pada Sekolah Menengah Pertama Negeri 1 Donorojo Kabupaten Pacitan. Indonesian Journal on Networking and Security. Vol. 3, No. 4: 57-64.

Juansyah, Andi. (2015). Pembangunan Aplikasi Child Tracker Berbasis Assited-Global Positioning System (A-GPS) dengan Platform Android. Jurnal Ilmiah Komputer dan Informatika (KOMPUTA). Vol. 1, No. 1:1-8.

Madcoms. (2016). Pemrograman PHP dan MySQL untuk Pemula. Andi. Yogyakarta. Prasetyo, Sigit.(2011). Pengembangan Sistem Informasi Penggajian. (Studi kasus: SMK $A l$-Firdaus). Jakarta: Fakultas Sains dan Teknologi UIN Syarif Hidayatullah.

Rahmawati, Silvia dan Shalahuddin. Proses Seleksi Karyawan Baru Bagian Sales pada PT Mitra Sukses Bersama Berkasi. Jurnal Administrasi Kantor. Vol. 5, No. 1: 99-106.

Rosa, dkk. (2013). Rekayasa Perangkat Lunak Terstruktur dan Berorientasi Objek. Bandung: Informatika.

Sodikin. (2011). Perancangan Sistem Penggajian dengan Hak Akses Karyawan Berbasis Web. (Studi Kasus: PK Gaya Baru). Jakarta: Fakultas Sains dan Teknologi UIN Syarif Hidayatullah.

Susanti, Melan. (2016). Perancangan Sistem Informasi Akademik Berbasis Web pada SMK Pasar Minggu Jakarta. Jurnal Informatika. Vol. 3, No. 1: 91-99. 